CATALLAXY

Volume 3 Issue 2 December 2018

e-ISSN 2544-090X

¿ www.catallaxy.pl

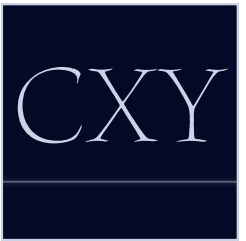

Oryginalny artykut naukowy

otrzymano: 08.05.2018 / zaakceptowano: 25.06.2018 / opublikowano online: 30.06 .2018

Kasprowicz, P., i Pietraszko, P. (2018). Wsparcie regionalne a inwestycje zaawansowane technologicznie: ocena oddziaływania „Programu wspierania inwestycji o istotnym znaczeniu dla gospodarki polskiej na lata 2011-2023” na decyzje inwestorów. Catallaxy, 3(2): 69-79. doi:10.24136/cxy.2018.008.

Wsparcie regionalne a inwestycje zaawansowane technologicznie: ocena oddziaływania „Programu wspierania inwestycji o istotnym znaczeniu dla gospodarki polskiej na lata 2011-2023" na decyzje inwestorów

\title{
PAWEE KASPROWICZ
}

autor korespondencyjny

Szkoła Główna Handlowa w Warszawie, al. Niepodległości 162, 02-554 Warszawa, Polska

వprkasprowicz@gmail.com

(iD) orcid.org/0000-0003-1696-5504

\section{PAWEE PIETRASZKO}

Szkoła Główna Handlowa w Warszawie, Polska

వpp56861@sgh.waw.pl

(D) orcid.org/0000-0001-8964-4838

\section{Abstrakt}

Motywacja: W 2011 roku Rada Ministrów wprowadzila Program wspierania inwestycji o szczególnym znaczeniu dla gospodarki polskiej na lata 2011-2020. Głównym jego celem jest zachęcanie inwestorów zagranicznych do lokowania w Polsce inwestycji zaawansowanych technologicznie. Jednocześnie zawarto w nim kryteria lokalizacyjne mające zachęcać do inwestycji w słabiej rozwiniętych regionach. Motywem wyboru tematu jest zbadanie, w jaki sposób oba aspekty programu wpływają na decyzje lokalizacyjne inwestorów zagranicznych.

Cel: Celem artykułu jest próba oceny wpływu czynników lokalizacyjnych, powiązanych ze specyfiką wspieranych przez program typów inwestycji oraz bezpośrednich zachęt w nim zawartych na decyzje inwestorów zagranicznych.

Materiały i metody: Pozyskano informacje dotyczące projektów z publicznie dostępnych źródeł, jak również instytucji zaangażowanej w obsługę inwestorów zagranicznych. Dane powiązano ze sobą oraz poddano analizie z wykorzystaniem pakietu ekonometrycznego.

Wyniki: Analiza wskazała zróżnicowany wpływ programu na inwestycje w poszczególne typy projektów w zależności od lokalizacji, jednak w ograniczonym zakresie.

Stowa kluczowe: bezpośrednie inwestycje zagraniczne; Polska; pomoc publiczna; teoria lokalizacji JEL: C2O; C50; DOO; H25; R39 


\section{Wprowadzenie}

Rozwój gospodarczo-społeczny nieodłącznie powiązany jest $z$ inwestycjami oraz wzrostem zaawansowania technik wytwórczych. Gospodarka wykorzystująca coraz bardziej zaawansowaną technologię i coraz efektywniejsze metody zarządzania, stale rozwija swoje zdolności produkcyjne i potencjał do wzrostu poziomu wytwarzanej wartości dodanej, a co za tym idzie - PKB. Dla gospodarek doganiających państwa bogatsze, ważnym elementem tego procesu są bezpośrednie inwestycje zagraniczne (BIZ). Inwestorzy zagraniczni, przeznaczając środki na inwestycje, planują wykorzystanie dostępnych w danym państwie zasobów (materialnych i niematerialnych) w celu maksymalizacji korzyści. O prócz inwestycji w środki trwałe (maszyny, budynki), niezmiernie ważnym wkładem inwestorów są wnoszone przez nich wartości niematerialne takie, jak: technologia, skuteczne metody zarządzania, sieć ponadnarodowych kontaktów i powiązań, know-how.

$Z$ punktu widzenia danej gospodarki ważne jest, aby możliwie dużą część tych niematerialnych zasobów trwale ulokować w państwie oraz doprowadzić do ich rozpowszechnienia. Brak tego typu procesów, lub lokowanie w państwie jedynie procesów opartych na wykorzystaniu konkurencyjnej cenowo siły roboczej, skutkować może pojawieniem się tzw. „pułapki średniego dochodu”. Występuje ona, gdy poziom dochodów ludności wzrasta jedynie do pewnego poziomu, ale nie jest w stanie zbliżyć się do poziomu państw doganianych. Gospodarka, której atutem są jedynie niskie koszty pracy, musi tracić atrakcyjność wraz ze wzrostem tych kosztów (rosną one wraz $z$ rozwojem społecznym). Dochodzi wtedy do sytuacji, w której przy pewnym, ustalonym poziomie zamożności społeczeństwa (niższym, niż w państwach bogatych), dana gospodarka nie jest już atrakcyjnym miejscem docelowym dla BIZ i w efekcie zatrzymuje się dalszy wzrost gospodarczy (wcześniej generowany przez inwestycje zagraniczne).

Istnieje więc potrzeba pojawienia się $\mathrm{w}$ gospodarce zaawansowanych technologicz- nie i organizacyjnie inwestycji zagranicznych, które nie tylko wykorzystują dostępne zasoby siły roboczej, ale które prowadzą do pobudzenia rozwoju kapitału ludzkiego, trwałego rozpowszechnienia nowych metod produkcji i zarządzania, a tym samym trwale zwiększają efektywność, pozwalając na dalszy rozwój gospodarczy. $Z$ tego typu założenia wyszedł polski rząd wprowadzając Program wspierania inwestycji o szczególnym znaczeniu dla gospodarki polskiej na lata 2011-2020, przedłużony następnie do 2023 roku. Ma on wspierać napływ inwestycji zaawansowanych technicznie służących rozwojowi kapitału ludzkiego. Premiowane są inwestycje w strategiczne sektory przemysłowe, jak również w sektor usługowy i badawczo-rozwojowy.

Równocześnie $z$ realizacją wspomnianego celu, program posiada również równoległy cel wspierania rozwoju regionalnego w obrębie państwa. Osiągnięte ma to zostać poprzez dodatkowe premiowanie inwestycji w regionach słabiej rozwiniętych (tzw. „ściana wschodnia", regiony o wyższej stopie bezrobocia). Można jednak zauważyć, że potencjalnie oba cele wymagają działań $w$ przeciwstawnych kierunkach. $\mathrm{O}$ ile inwestycje $\mathrm{w}$ procesy zaawansowane technicznie powiązane są $z$ lokalizowaniem ich raczej $w$ obszarach lepiej rozwiniętych, tj. mających dobry dostęp do kadry akademickiej, rozwiniętego rynku pracy oraz do potencjalnych klientów, o tyle inwestycje mające na celu niwelowanie różnic rozwojowych $\mathrm{w}$ zamierzeniu miały być premiowane za lokalizowanie $\mathrm{w}$ ich regionach słabiej rozwiniętych. Innymi słowy, $z$ konkretnymi grupami inwestycji, wspieranymi w ramach programu, powiązane mogą być konkretne czynniki lokalizacyjne, zgodne lub niezgodne z celem pomocy regionalnej.

Celem artykułu jest próba oceny wpływu czynników lokalizacyjnych, powiązanych ze specyfiką wspieranych przez program typów inwestycji oraz bezpośrednich zachęt w nim zawartych na decyzje inwestorów zagranicznych.

W sekcji 2. dokonano przeglądu literatury w podziale na charakterystykę programu wspierania oraz prezentację publikacji $z$ za- 
kresu teorii lokalizacji. W sekcji 3. omówiono wykorzystane materiały i metody. W sekcji 4. zaprezentowano uzyskane wyniki, natomiast $\mathrm{w}$ sekcji 5. podsumowano wyciągnięte wnioski.

\section{Przegląd literatury}

Podstawowym źródłem, wykorzystywanym $\mathrm{w}$ niniejszym artykule jest załącznik do uchwały Rady Ministrów ustanawiającej opisywany program, a zawierający jego treść (Komunikat Ministra Gospodarki, 2011). Ponadto, $z$ uwagi na odniesienia do teorii lokalizacji, dokonano przeglądu powiązanej literatury charakteryzującej czynniki lokalizacyjne.

\subsection{Program wspierania}

Program wspierania inwestycji o znaczacym znaczeniu dla gospodarki polskiej na lata 2011-2023 podzielony jest na trzy główne części. Pierwsza $z$ nich stanowi teoretyczne uzasadnienie potrzeby wspierania inwestycji o szczególnym znaczeniu dla gospodarki, jak również ocenę pod tym kątem gospodarki polskiej. Wynika z niej, że Polska jest państwem mogącym osiągnąć wysokie korzyści z BIZ, jak również mającym potencjał do pozyskiwania inwestycji zaawansowanych i późniejszej absorpcji napływającej technologii (Rada Ministrów, 2011, s. 17).

Drugą część stanowią cele programu. Jako cel główny wskazano wzrost konkurencyjności oraz innowacyjności polskiej gospodarki. Świadczy to o tym, że twórcy programu są świadomi potrzeby rozwoju gospodarki na tym polu. Wskazane są również dwa cele szczegółowe: wzrost udziału innowacyjnych inwestycji stosujących nowoczesne technologie oraz tworzenie miejsc pracy o wysokiej produktywności. Cele te precyzyjnie kierunkują program na tworzenie zachęt dla zewnętrznych źródeł kapitału finansujących określone typy inwestycji, lokowane w Polsce. Równocześnie do programu włączono priorytety dotyczące "wewnętrznego" rozmieszczenia inwestycji w gospodarce, a mianowicie elementy lokalizacyjne kierujące inwestycje do słabiej rozwiniętych regionów (Rada Ministrów, 2011, s. 18).

Cele te odzwierciedlone są $w$ trzeciej części programu zawierającej opis procedury wsparcia. W programie punktowano inwestycje według określonego schematu, a od uzyskanego wyniku uzależniono przyznanie wsparcia, jak również jego wysokość. Ocena zróżnicowana jest na dwóch płaszczyznach: po pierwsze, czy jest to inwestycja w sektorze przemysłowym, usługowym czy badawczo-rozwojowym (Rada Ministrów, 2011, s. 28), po drugie, czy jest to wsparcie w obrębie wielkości planowanych inwestycji czy w obrębie liczby planowanych miejsc pracy (Rada Ministrów, 2011, s. 27). Inwestycje mają różne kryteria oceny w zależności od typu. W przypadku, przemysłowych wymagane jest, aby były one $z$ grupy tzw. sektorów priorytetowych: biotechnologicznego, motoryzacyjnego, lotniczego, rolno-spożywczego, elektronicznego i AGD. Przy odpowiednio dużych inwestycjach, niezależnie od sektora, uznawano je za tzw. „inwestycje znaczące” i również dopuszczano do programu. Sektory priorytetowe były różnie punktowane w zależności od stopnia ich zaawansowania technologicznego. Podobny sposób punktacji zastosowano wobec projektów usługowych i badawczo-rozwojowych. W tym przypadku punktowane były konkretne grupy procesów przeprowadzanych $w$ ramach planowanej działalności (Rada Ministrów, 2011, s. 33). Niezależnie od typu inwestycji, w większym stopniu wspierano inwestycje w tzw. „Polsce wschodniej” (województwa: warmińsko-mazurskie, podlaskie, lubelskie, świętokrzyskie i podkarpackie), jak również w powiatach o wyższym poziomie bezrobocia (regiony słabiej rozwinięte).

Program został oceniony przez Najwyzszą Izbę Kontroli (NIK, 2017) w 2017 roku. NIK przeanalizowała udzielone wsparcie oraz zaprezentowała wnioski $w$ publikacji podsumowującej kontrolę. Wśród projektów ujętych w programie najliczniejszą grupę stanowiły inwestycje w sektor nowoczesnych usług. Ta grupa inwestycji tworzyła również największą liczbę miejsc pracy. Natomiast, 
ze względu na nakłady inwestycyjne, najbardziej kapitałochłonne były inwestycje produkcyjne. Wskazuje to na fakt, że część projektów miała charakter pracochłonny, a część kapitałochłonny, przy czym rozgraniczenie między tymi grupami pokrywa się z grupami wyróżnionymi $w$ ramach działania programu (inwestycje usługowe/przemysłowe). Innymi słowy, inwestycje $\mathrm{w}$ nowoczesne usługi charakteryzowały się wysokim zatrudnieniem, ale relatywnie niskimi nakładami inwestycyjnymi, natomiast inwestycje przemysłowe - odwrotnie. Jest to ważna obserwacja $z$ uwagi na zróżnicowany wpływ czynników lokalizacyjnych na różne typy inwestycji.

\subsection{Teoria lokalizacji}

W sekcji 2.2. przedstawiono krótką charakterystykę najważniejszych pojęć dotyczących teorii lokalizacji.

Przytaczając A. Webera, W. Budner (2007, s. 45), wskazuje trzy podstawowe, klasyczne czynniki lokalizacji: koszty transportu, koszty pracy i korzyści aglomeracji. Podział czynników można również ująć w ramach walorów zasobu i walorów popytu. Pierwsze $z$ nich, to czynniki pozwalające $w$ danym miejscu uzyskać warunki do prowadzenia działalności. Natomiast drugie, to czynniki atrakcyjne $z$ uwagi na możliwość zbytu produktów przedsiębiorstwa. Można zwrócić uwagę na fakt, że dla inwestycji przemysłowych, ważniejszym aspektem może być dostęp do surowców oraz niskich kosztów transportu. Usługi natomiast bardziej korzystają z bliskości usługobiorców, jak również rynku pracy zapewniającego pracowników.

W. Wierzbicka (2015, s. 242), zauważa, że w zakresie postrzegania czynników lokalizacyjnych następują znaczne zmiany, szczególnie od lat 80. XX wieku. Zwraca uwage na odejście od ekonomii ilości do ekonomii jakości oraz od konkurencji kosztowej do jakościowej. Zmiany te mają związek z działalnością w zakresie zaawansowanych technicznie produktów i usług, a więc są szczególnie interesujące $z$ punktu widzenia celów programu. $\mathrm{W}$ tej grupie ujmuje ona m.in.: kapitał ludzki, kapitał społeczny oraz innowacyjność regionu. Czynniki tego typu powiązane są natomiast $z$ jakością edukacji w danym miejscu. Podejście to prezentuje B. Skubiak (2013, s. 197), akcentując wieloaspektowe korzyści wynikające z wysokiej jakości szkolnictwa. D. Rynio (2010, ss. 106-107), natomiast wskazuje na fakt, że zagraniczni inwestorzy często kierują kapitał do miejsc wcześniej rozpoznanych przez inne przedsiębiorstwa. W związku z tym, określa potencjalne znaczenie metropolii jako czynnika przyciągającego inwestorów. Wiąże $z$ nią (oprócz koncentracji inwestorów), także liczebność transakcji i wysoką sprawność zawiązywania relacji między podmiotami. Jako ważną obserwację wskazuje, że powyższe wnioski dotyczą w szczególności podmiotów produkujących/wykonujących tzw. produkty/ usługi wyższego rzędu.

W oparciu o charakterystyki czynników lokalizacji powiązane $z$ zaawansowanymi technicznie produktami i czynnikami, możliwy był wybór charakterystyk objętych programem, które poddane były analizie w niniejszym artykule.

\section{Materiały i metody}

Pierwszym etapem realizacji celu niniejszego artykułu była analiza programu i kryteriów oceny w świetle teorii lokalizacji. Dokonano przeglądu literatury w tym zakresie, co pozwoliło na identyfikację czynników lokalizacyjnych potencjalnie wpływających szczególnie silnie na inwestycje wspierane $w$ ramach programu. Premiowano w nim inwestycje tworzące dużą liczbę miejsc pracy i zatrudnianie osób z wyższym wykształceniem. Wskazuje to, że dla inwestorów biorących udział w programie, atrakcyjne mogą być lokacje w pobliżu centrów miejskich i aglomeracji, które zapewniają dostęp do rozbudowanego rynku pracy oraz kadr akademickich i absolwentów. Znaczenie aglomeracji potencjalnie może potwierdzać również zaawansowany charakter planowanych procesów $w$ ramach projektów objętych programem. Podobny wpływ mógł mieć dobór sektorów priorytetowych, wśród 
których dominują te, wymagające zatrudnienia wykwalifikowanych kadr.

Przy wyborze zmiennych do modelu kierowano się kryterium ich powiązania $z$ konstrukcją programu. Analizowano więc zmienne bezpośrednio $\mathrm{w}$ nim ujęte lub reprezentujące cechy, do których się odnosił. $Z$ uwagi na konstrukcję oceny projektów w programie, jako czynniki lokalizacji mogące oddziaływać na inwestorów przyjęto poziom bezrobocia (ogółem oraz wśród osób $z$ wyższym wykształceniem), jak również ulokowanie danego projektu $\mathrm{w}$ specjalnej strefie ekonomicznej (SSE). SSE nie były bezpośrednio włączone do programu, jednak wysokość grantu $w$ ramach programu uzależniona była od innych form wsparcia, jakie otrzymywał projekt, $\mathrm{w}$ tym również ze stref. Ponadto, fakt położenia w Polsce wschodniej bezpośrednio był promowany przez system punktacji w programie.

Podstawowe informacje i statystyki o realizowanych $w$ badanym przedziale czasu projektach inwestycyjnych (w tym uczestniczących w programie wspierania) pozyskano $z$ Polskiej Agencji Inwestycji i Handlu (PAIH). Instytucja ta jednak nie mogła przekazać pełnej listy projektów wraz $z$ ich szczegółami. Udało się jednak uzyskać podstawowe statystyki ich dotyczące, w tym lokalizacje. Dane te obejmowały projekty z lat 2011-2016. Wśród informacji znajdowały się charakterystyki projektów takie, jak: obecność w programie, rok zakończenia projektu inwestycyjnego, obecność w SSE, planowane nakłady inwestycyjne oraz planowane zatrudnienie. Ważnym elementem była informacja o sektorze działalności. Dane te jednak nie mogą być udostępnione poza zespół badaczy, nie są więc publikowane w niniejszym artykule. $Z$ zestawu dostępnych obserwacji wybrano jedynie te projekty, które w świetle formalnych wymagań programu mogły potencjalnie zostać jego beneficjentami.

Pozyskane $\mathrm{w}$ ten sposób dane uzupełniono powszechnie dostępnymi statystykami dotyczącymi rynku pracy: stopą bezrobocia rejestrowanego $\mathrm{w}$ powiecie (jako wskaźnika odnoszącego ją do stopy w skali państwa) oraz stopą bezrobocia osób $z$ wyższym wy- kształceniem (analogiczny wskaźnik). Dane te pozyskano z prowadzonego przez Główny Urząd Statystyczny (GUS) Banku Danych Lokalnych (BDL, 2018), w podziale na powiaty i lata (dane przyporządkowano do projektów biorąc pod uwagę miejsce i rok zakończenia projektu inwestycyjnego). Stopa bezrobocia wśród osób $z$ wyższym wykształceniem nie jest publikowana przez GUS bezpośrednio na poziomie powiatów. W celu jej wyznaczenia skorzystano ze wzoru (1) oraz wzoru (2):

$$
\begin{aligned}
& S_{b}=\frac{U \cdot 100}{U+E}, \\
& S_{b w}=\frac{U_{w} \cdot 100}{U+E},
\end{aligned}
$$

gdzie:

$S_{b}$ - stopa bezrobocia;

$S_{b w}$ - stopa bezrobocia osób z wyższym wykształceniem;

$U$ - liczba bezrobotnych;

$U_{w}$ - liczba bezrobotnych z wyższym wykształceniem;

E - liczba zatrudnionych.

Definicja stopy bezrobocia osób $z$ wyzszym wykształceniem we wzorze (2), wprost została zawarta w programie (Rada Ministrów, 2011, s. 38). Natomiast stopę bezrobocia ogółem obliczono według wzoru (1) (Głuszczuk i Raszkowski, 2016, s. 23).

Przy tak zdefiniowanych stopach bezrobocia oraz dostępnej w BDL (2018) informacji (na odpowiednim poziomie agregacji oraz w odpowiednim okresie) o liczbie osób bezrobotnych oraz liczbie osób bezrobotnych z wyższym wykształceniem, wyznaczono szukaną stopę wzorem (3):

$$
S_{b w}=S_{b} \cdot \frac{U_{w}}{U} .
$$

Następnie, otrzymane stopy $\mathrm{w}$ poszczególnych powiatach odniesiono do tak wyznaczonej stopy na poziomie całego państwa otrzymując właściwy wskaźnik.

Wyznaczono również projekty, które znajdowały w ośrodkach miejskich, w których znajdują się największe, polskie uniwersytety (według rankingu Perspektywy (2017)). 
W tym celu wykorzystano usługę mapową Google. Zauważyć należy, że zestaw najważniejszych uniwersytetów pokrywal zbiór najważniejszych ośrodków miejskich w państwie. Zmienną tę można alternatywnie potraktować, jako opisującą obecność danych inwestycji w ważnych ośrodkach miejskich, definiowanych poprzez jakość dostępnego $\mathrm{w}$ nich kształcenia na poziomie akademickim. Dodatkowo, dla każdej inwestycji (a dokładnie dla powiatu, w którym była ona lokowana), wyznaczono odległość do najbliższej, dużej uczelni technicznej (według rankingu Perspektywy (2017)). W tym celu wykorzystano narzędzie Google Maps Distance Matrix API, które dla wybranych par punktów zwracało odległość między nimi. Wykorzystując przygotowany na potrzeby badania skrypt, odpytano seryjnie narzędzie uzyskując dla każdego projektu (według powiatu, w którym się znajduje) odległości do wszystkich, wyszczególnionych uczelni, a następnie wybierano odległość najmniejszą.

Wykorzystując tak pozyskane informacje, przygotowano zestaw danych każdemu projektowi przyporządkowujący zestaw jego charakterystyk (tabela 1.). Następnie zaimportowano je do programu Gretl w celu przeprowadzenia analizy. Rozważono kilka modeli. W przypadku, gdy zmienna objaśniana miała charakter binarny, użyto modelu logitowego, w przeciwnym przypadku - klasycznej metody najmniejszych kwadratów (KMNK). Modelowanie binarnej zmiennej zależnej interpretowane może być jako modelowane prawdopodobieństwa. Wykorzystanie liniowego modelu prawdopodobieństwa nie gwarantuje uzyskania wartości zmiennej objaśnianej z przedziału $[0,1]$. Własność tę zapewnia model logitowy. Użyty w przeprowadzonej analizie, można opisać równaniami (4) i (5):

$$
\begin{aligned}
& \operatorname{logit}\left(p_{i}\right)=Z_{i}=\beta_{0}+\beta_{1} X_{1 i}+ \\
& +\beta_{2} X_{2 i}+\ldots+\beta_{k} X_{k i}, \\
& \operatorname{logit}\left(p_{i}\right)=Z_{i}=\ln \left(\frac{p_{i}}{1-p_{i}}\right),
\end{aligned}
$$

gdzie:

$p_{i}$ - prawdopodobieństwo przyjęcia przez zmienną objaśnianą danej wartości;

$\beta_{0}, \beta_{1}, \ldots, \beta_{k}$ - parametry modelu;

$X_{1 i}, \ldots, X_{k i}-z$ mienne objaśniające.

Użyte dane mają charakter mikrodanych. Cechą charakterystyczną tego typu analizy są stosunkowo niskie wartości współczynnika determinacji $R^{2}$. Ponadto w przypadku modeli logitowych, zamiast współczynnika $R^{2}$ wykorzystuje się współczynnik „Pseudo- $R^{2}$ ” McFaddena, który również przyjmuje wartości z przedziału [0,1] (Gruszczyński, 2012, s. 80-86). Zazwyczaj są one dużo niższe, niż dla współczynnika $R^{2}$ w modelach liniowych i już wartości z przedziału $[0,2-0,4]$ oznaczają wysokie dopasowanie (McFadden, 1977).

$Z$ uwagi na charakter danych oraz niewielką liczbę obserwacji, zrezygnowano $z$ analizy wartości otrzymanych $w$ modelach współczynników (KMNK) i efektów krańcowych (modele logitowe). Szukano istotnych statystycznie zależności oraz zbadano znak uzyskanych wartości. W tym celu tworzono wstępny model zawierający pełen zestaw danych, a następnie sekwencyjnie usuwano nieistotne statystycznie zmienne (przy przyjętym poziomie istotności $\alpha=0,1)$. Szacowane modele oraz wyniki zaprezentowano $w$ tabelach 2. -6 .

\section{Wyniki badania}

W badaniu sprawdzono wpływ programu na decyzje inwestycyjne, dokonane $w$ danych branżach, podzielone na trzy grupy: inwestycje w sektor nowoczesnych usług, badań i rozwoju oraz przemysłowy. Przeprowadzono również analizę wpływu programu na decyzje inwestorów, którzy zdecydowali się zainwestować $w$ regionach gorzej rozwiniętych (w powiatach $z$ ponadprzeciętną stopą bezrobocia lub należących do województw wschodnich) lub lepiej (w pozostałych).

Program pozytywnie korelowal $z$ wysokością nakładów inwestycyjnych $\mathrm{w}$ sektorach przemysłowych. Może to oznaczać, że środki $z$ programu trafiały przede wszystkim do du- 
żych przedsiębiorstw, lub że program skutecznie przyciągał duże inwestycje do państwa.

W przypadku inwestycji w przemyst, program sprzyjał również lokowaniu ich w regionach o wyższej stopie bezrobocia. Na terenach rozwiniętych, uczestnictwo $\mathrm{w}$ programie było negatywnie skorelowane $z$ prawdopodobieństwem dla inwestycji w sektor przemysłowy.

$W$ przeciwieństwie do inwestycji w przemysł, w przypadku inwestycji w usługi, występowała negatywna korelacja między wysokością nakładów inwestycyjnych a uczestnictwem w programie. Może to oznaczać, że w przypadku inwestycji usługowych, największe nakładowo inwestycje, dokonywane były przez podmioty, które dokonują ich bez wsparcia, lub że przedsiębiorstwa planujące inwestycje o wysokości nakładów zbliżonych do minimalnych, wymaganych przez program, zwiększają je tylko na tyle, aby otrzymać wsparcie.

$\mathrm{Na}$ terenach lepiej rozwiniętych uczestnictwo $w$ programie korelowało $z$ inwestycja w usługi. Może to wskazywać na przyciąganie przez program zaawansowanych inwestycji $\mathrm{w}$ usługi, lecz również $z$ możliwości skorzystania $z$ programu przez inwestycje tego typu już planowane. Występowanie tego efektu na terenach rozwiniętych, prawdopodobnie wynika $z$ faktu lokowania zaawansowanych centrów usługowych w miastach.

W przypadku inwestycji w badania i rozwój, program nie wpłynął istotnie na żadną, badaną zmienną decyzyjną.

\section{Zakończenie}

W przypadku strategicznych inwestycji przemysłowych w skali państwa odnotowano wpływ ponadprzeciętnej stopy bezrobocia na prawdopodobieństwo ulokowania tego typu inwestycji. Natomiast program ujemnie wpływał na prawdopodobieństwo lokowania tego typu inwestycji $w$ regionach lepiej rozwiniętych, na rzecz regionów rozwiniętych słabiej. Potencjalnie może to wskazywać, że program, pod tym względem, działał przede wszystkim jako element polityki rozwoju regionalnego.
Programem objęte były raczej mniejsze, pod kątem nakładów inwestycyjnych, projekty usługowe. W tej kategorii zauważyć można tendencję, że program stanowił zachętę, by inwestorzy inwestowali minimalną kwotę, kwalifikującą do programu, nie miał jednak wpływu na duże inwestycje usługowe.

$\mathrm{W}$ analizie nie zaobserwowano istotnego statystycznie wpływu programu na inwestycje badawczo-rozwojowe. Może to wskazywać na niską efektywność programu w tym zakresie i potrzebę lepszego dostosowania go pod tym względem $\mathrm{w}$ przyszłości.

Analiza nie pokazała statystycznie istotnego wpływu oddziaływania programu na inne czynniki lokalizacyjne. Formułując wnioski należy jednak pamiętać, że $z$ uwagi na charakter programu i czas jego trwania, próba badawcza była stosunkowo niewielka, natomiast dane miały mikroekonomiczny charakter. Sprawia to, że wnioski mogą być formułowane w sposób przybliżony, a kolejne analizy, uzupełnione o większą ilość danych, mogą być interesującym polem dalszych badań.

\section{Bibliografia}

Bank Danych Lokalnych. (2018). Pobrane 18.05.2018 z https://bdl.stat.gov.pl.

Budner, W. (2007). Czynniki lokalizacji inwestycji a możliwości rozwoju ekonomicznego gmin w Polsce. Acta Scientiarum Polonorum. Administratio Locorum, 6(3).

Głuszczuk, D., i Raszkowski, A. (2016). Stopa bezrobocia: mankamenty pomiaru i próba ich eliminacji. Ekonomia XXI wieku, 2(10). doi:10.15611/e21.2016.2.02.

Gruszczyński, M., (2012). Mikroekonometria: modele $i$ metody analizy danych indywidualnych. Warszawa: Wolters Kluwer.

Komunikat Ministra Gospodarki z dnia 18 sierpnia 2011 r. o podjęciu przez Radę Ministrów uchwały w sprawie przyjęcia programu rozwoju pod nazwą „Program wspierania inwestycji o istotnym znaczeniu dla gospodarki polskiej na lata 2011-2020" (M.P. $2011 \mathrm{nr} 82$ poz. 834).

McFadden, D. (1977). Quantitative methods for analyzing travel behaviour of individuals: some recent developments. Cowles Foundation Discussion Paper, 474. 
Najwyższa Izba Kontroli. (2017). Realizacja programu wspierania inwestycji o istotnym znaczeniu dla gospodarki polskiej na lata 2011-2020. Pobrane 18.05.2018 z https://www.nik.gov.pl.

Perspektywy. (2017). Ranking uczelni akademickich 2016. Pobrane 18.05.2018 z http://www.perspektywy.pl.

Rada Ministrów. (2011). Program wspierania inwestycji o istotnym znaczeniu dla gospodarki polskiej na lata 2011-2020. Pobrane 18.05.2018 z http://www.paiz.gov.pl.

Rynio, D. (2010). Atrakcyjność lokalizacji inwestycji zagranicznych w metropolii. Acta Universitatis Lodziensis. Folia Oeconomica, 246.

Skubiak, B. (2013). Edukacja jako czynnik wspierający rozwój gospodarczy. Implikacje dla Polski. Studia Ekonomiczne. Zeszyty Naukowe Uniwersytetu Ekonomicznego w Katowicach, 129.

Wierzbicka, W. (2015). Czynniki lokalizacji przedsiębiorstw w warunkach zmienności otoczenia. Zeszyty Naukowe Uniwersytetu Przyrodniczo-Humanistycznego w Siedlcach. Seria: Administracja i Zarzadzanie, 106.
Informacje uzupetniające

Wkład autorski: autorzy zaakceptowali ostateczną wersję artykułu. Ich wkład w powstanie artykułu jest jednakowy.

Źródła finansowania: artykuł został w całości sfinansowany ze środków własnych autorów.

Podziękowania autorskie: autorzy składają podziękowania za pomoc w przygotowaniu artykułu następującej instytucji: Polska Agencja Inwestycji i Handlu SA.

Uwagi: wyniki badania byly zaprezentowane na VIII Ogólnopolskiej Konferencji Naukowej z cyklu Problemy gospodarki światowej (Toruń, 20.04.2018). 
Aneks

Tabela 1.

Analizowane wskaźniki

\begin{tabular}{|c|c|c|}
\hline Zmienna & Opis & Źródła \\
\hline wschod & czy powiat znajdowal się w województwie polski wschodniej? & PAIH \\
\hline program & czy inwestycja była objęta programem? & PAIH \\
\hline unemployment & stopa bezrobocia w powiecie & BDL (2018) \\
\hline stopa_wyzsze & stopa bezrobocia osób z wyższym wykształceniem w powiecie & BDL (2018) \\
\hline uni & $\begin{array}{l}\text { czy w powiecie lub w powiecie sąsiadującym znajdowała się uczelnia } \\
\text { wyższa posiadająca przynajmniej jeden wydział w pierwszej dziesiątce } \\
\text { rankingu Perspektywy (2017) }\end{array}$ & $\begin{array}{l}\text { Perspektywy (2017), } \\
\text { Google Maps }\end{array}$ \\
\hline uni_true & $\begin{array}{l}\text { czy w powiecie znajdowała się uczelnia wyższa posiadająca przynajmniej } \\
\text { jeden wydział w pierwszej dziesiątce rankingu Perspektywy (2017) }\end{array}$ & Perspektywy (2017) \\
\hline uni_dist & odległość do powiatu, w którym znajduje się uczelnia techniczna (w km) & $\begin{array}{l}\text { Perspektywy (2017), } \\
\text { Google Distance Matrix API }\end{array}$ \\
\hline$b r$ & czy inwestycja była inwestycją w badania i rozwój? & PAIH \\
\hline serv & czy inwestycja była inwestycją w sektorze usług? & PAIH \\
\hline industry & $\begin{array}{l}\text { czy inwestycja była inwestycją w sektor przemysłowy ( } z \text { wyłączeniem } \\
\text { sektorów strategicznych)? }\end{array}$ & PAIH \\
\hline strateg & czy inwestycja była inwestycją strategiczną? & PAIH \\
\hline investment & planowana wysokość inwestycji ( $w$ mln EUR) & PAIH \\
\hline employ & planowane zatrudnienie & PAIH \\
\hline sse & czy inwestycja korzystała ze wsparcia w ramach SEE? & PAIH \\
\hline I_(zmienna) & logarytm naturalny danej zmiennej & - \\
\hline
\end{tabular}

Źródło: Opracowanie własne.

Tabela 2.

Wyniki estymacji modelu logitowego (udział w programie a prawdopodobieństwo, że projekt jest typu usługowego, regiony dobrze rozwinięte, zmienna objaśniana: serv)

\begin{tabular}{|c|c|c|}
\hline Zmienna & Ocena parametru & Wartośćp \\
\hline stała & $-2,5775$ & 0,5762 \\
\hline I_stopa_wyzsze & 2,2152 & 0,0431 \\
\hline l_unemployment & $-1,9946$ & 0,0044 \\
\hline program & 0,8960 & 0,0454 \\
\hline Własności statystyczne modelu & Statystyka testu & Wartośćp \\
\hline test ilorazu wiarygodności & 15,5137 & 0,0014 \\
\hline McFadden $R^{2}$ & \multicolumn{2}{|c|}{0,1114} \\
\hline liczba przypadków „poprawnej predykcji” & \multicolumn{2}{|c|}{$65,0 \%$} \\
\hline
\end{tabular}

Źródło: Opracowanie własne. 
Tabela 3.

Wyniki estymacji modelu logitowego (udział w programie a prawdopodobieństwo, że projekt jest typu przemysłowego, regiony dobrze rozwinięte, zmienna objaśniana: industry)

\begin{tabular}{|c|c|c|}
\hline Zmienna & Ocena parametru & Wartość p \\
\hline stała & 1,7075 & 0,0299 \\
\hline program & $-2,9493$ & 0,0178 \\
\hline sse & 2,8980 & 0,0007 \\
\hline uni_true & $-4,5187$ & $<0,0001$ \\
\hline Własności statystyczne modelu & Statystyka testu & Wartość p \\
\hline test ilorazu wiarygodności & 81,3587 & 0,0000 \\
\hline McFadden $R^{2}$ & \multicolumn{2}{|c|}{0,6457} \\
\hline liczba przypadków „poprawnej predykcji” & \multicolumn{2}{|c|}{$91,3 \%$} \\
\hline
\end{tabular}

Źródło: Opracowanie własne.

Tabela 4.

Wyniki estymacji modelu logitowego (udział w programie a prawdopodobieństwo, że projekt jest typu przemysłowego, regiony z ponadprzeciętnym bezrobociem, zmienna objaśniana: industry)

\begin{tabular}{|c|c|c|}
\hline Zmienna & Ocena parametru & Wartośćp \\
\hline stała & $-0,7673$ & 0,0222 \\
\hline program & 1,4604 & 0,0230 \\
\hline Własności statystyczne modelu & Statystyka testu & Wartośćp \\
\hline test ilorazu wiarygodności & 81,3587 & 0,0188 \\
\hline McFadden $R^{2}$ & \multicolumn{2}{|c|}{0,0728} \\
\hline liczba przypadków „poprawnej predykcji” & \multicolumn{2}{|c|}{$67,9 \%$} \\
\hline
\end{tabular}

Źródło: Opracowanie własne.

Tabela 5 .

Wyniki estymacji modelu KMNK (udział w programie a wysokość logarytmu nakładów inwestycyjnych w sektorze przemysłowym, zmienna objaśniana: $l$ investment)

\begin{tabular}{|c|c|c|c|}
\hline & Zmienna & Ocena parametru & Wartość p \\
\hline stała & & 3,5593 & 0,0000 \\
\hline program & & 0,9370 & 0,0056 \\
\hline & Własności statystyczne modelu & Statystyka testu & Wartośćp \\
\hline test $F$ & & 8,3378 & 0,0056 \\
\hline$R^{2}$ & & \multicolumn{2}{|c|}{0,1841} \\
\hline
\end{tabular}

Źródło: Opracowanie własne. 
Tabela 6.

Wyniki estymacji modelu KMNK (udział w programie a wysokość logarytmu nakładów inwestycyjnych w sektorze usługowym, zmienna objaśniana: $l$ _investment)

\begin{tabular}{|c|c|c|}
\hline Zmienna & Ocena parametru & Wartośćp \\
\hline stała & $-2,0009$ & 0,2301 \\
\hline program & $-0,7969$ & 0,0349 \\
\hline I_unemployment & 0,7667 & 0,0746 \\
\hline Własności statystyczne modelu & Statystyka testu & Wartośćp \\
\hline test F & 4,1824 & 0,0219 \\
\hline$R^{2}$ & \multicolumn{2}{|c|}{0,1629} \\
\hline
\end{tabular}

Źródło: Opracowanie własne.

Regional support and technologically advanced investments: assessment of the impact of the 'Program of supporting investments with significant importance for the Polish economy for 2011-2023' on investors' decisions

\footnotetext{
Abstract

Motivation: In 2011, the Council of Ministers introduced the "Program of supporting investments with significant importance for the Polish economy for 2011-2020'. Its main objective is to encourage foreign investors to locate hightech investments in Poland. At the same time, it includes location criteria to encourage investment in less developed regions. The motive for choosing the topic is to explore how both of the aspects of the Program affect the location decisions of foreign investors.

Aim: The aim of the articles is an attempt to assess the impact of location factors related to the specificity of investment types supported by the program and direct incentives included in the program on investors decisions.

Materials and methods: Information about projects was obtained from publicly available sources as well as from the institution involved in servicing foreign investors. The acquired data was related to each other and analyzed using the econometric software.

Results: The analysis indicated the varied impact of the program on investments in particular types of projects depending on the location, but to a limited extent.

Keywords: foreign direct investments; Poland; public aid; location theory JEL: C20; C50; DOO; H25; R39
} 
